NASA/TM-2004-213186

\title{
Advanced Technology Development for Stirling Convertors
}

Lanny G. Thieme and Jeffrey G. Schreiber

Glenn Research Center, Cleveland, Ohio 
Since its founding, NASA has been dedicated to the advancement of aeronautics and space science. The NASA Scientific and Technical Information (STI) Program Office plays a key part in helping NASA maintain this important role.

The NASA STI Program Office is operated by Langley Research Center, the Lead Center for NASA's scientific and technical information. The NASA STI Program Office provides access to the NASA STI Database, the largest collection of aeronautical and space science STI in the world. The Program Office is also NASA's institutional mechanism for disseminating the results of its research and development activities. These results are published by NASA in the NASA STI Report Series, which includes the following report types:

- $\quad$ TECHNICAL PUBLICATION. Reports of completed research or a major significant phase of research that present the results of NASA programs and include extensive data or theoretical analysis. Includes compilations of significant scientific and technical data and information deemed to be of continuing reference value. NASA's counterpart of peerreviewed formal professional papers but has less stringent limitations on manuscript length and extent of graphic presentations.

- TECHNICAL MEMORANDUM. Scientific and technical findings that are preliminary or of specialized interest, e.g., quick release reports, working papers, and bibliographies that contain minimal annotation. Does not contain extensive analysis.

- CONTRACTOR REPORT. Scientific and technical findings by NASA-sponsored contractors and grantees.
- CONFERENCE PUBLICATION. Collected papers from scientific and technical conferences, symposia, seminars, or other meetings sponsored or cosponsored by NASA.

- SPECIAL PUBLICATION. Scientific, technical, or historical information from NASA programs, projects, and missions, often concerned with subjects having substantial public interest.

- TECHNICAL TRANSLATION. Englishlanguage translations of foreign scientific and technical material pertinent to NASA's mission.

Specialized services that complement the STI Program Office's diverse offerings include creating custom thesauri, building customized databases, organizing and publishing research results ... even providing videos.

For more information about the NASA STI Program Office, see the following:

- Access the NASA STI Program Home Page at http://www.sti.nasa.gov

- E-mail your question via the Internet to help@sti.nasa.gov

- Fax your question to the NASA Access Help Desk at 301-621-0134

- Telephone the NASA Access Help Desk at 301-621-0390

- Write to:

NASA Access Help Desk

NASA Center for AeroSpace Information 7121 Standard Drive

Hanover, MD 21076 
NASA/TM-2004-213186

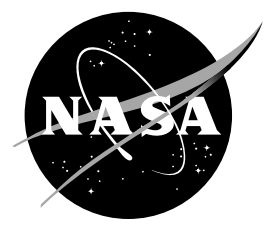

\section{Advanced Technology Development for Stirling Convertors}

Lanny G. Thieme and Jeffrey G. Schreiber

Glenn Research Center, Cleveland, Ohio

Prepared for the

Space Technology and Applications International Forum (STAIF-2004)

sponsored by the American Institute of Physics

Albuquerque, New Mexico, February 8-12, 2004

National Aeronautics and

Space Administration

Glenn Research Center 


\section{Acknowledgments}

The work described in this paper was performed for the Office of Space Science (Code S) and the Office of Aerospace Technology (Code R) at NASA Headquarters, both of which provided funding for these efforts. Work funded by DOE's Renewable Energy Laboratory in Golden, Colorado was also briefly discussed. Any opinions expressed are those of the authors and do not necessarily reflect the views of Project Prometheus.

Trade names or manufacturers' names are used in this report for identification only. This usage does not constitute an official endorsement, either expressed or implied, by the National Aeronautics and Space Administration.

Available from

NASA Center for Aerospace Information 7121 Standard Drive

Hanover, MD 21076
National Technical Information Service 5285 Port Royal Road Springfield, VA 22100 


\title{
Advanced Technology Development for Stirling Convertors
}

\author{
Lanny G. Thieme and Jeffrey G. Schreiber \\ National Aeronautics and Space Administration \\ Glenn Research Center \\ Cleveland, Ohio 44135 \\ E-mail: Lanny.G.Thieme @nasa.gov, Phone: 216-433-6119 \\ E-mail: Jeffrey.G.Schreiber@nasa.gov, Phone: 216-433-6144
}

\begin{abstract}
A high-efficiency Stirling Radioisotope Generator (SRG) for use on potential NASA Space Science missions is being developed by the Department of Energy, Lockheed Martin, Stirling Technology Company, and NASA Glenn Research Center (GRC). These missions may include providing spacecraft onboard electric power for deep space missions or power for unmanned Mars rovers. GRC is also developing advanced technology for Stirling convertors, aimed at substantially improving the specific power and efficiency of the convertor and the overall power system. Performance and mass improvement goals have been established for second- and third-generation Stirling radioisotope power systems. Multiple efforts are underway to achieve these goals, both in-house at GRC and under various grants and contracts. The status and results to date for these efforts will be discussed in this paper. Cleveland State University (CSU) is developing a multi-dimensional Stirling computational fluid dynamics code, capable of modeling complete convertors. A 2-D version of the code is now operational, and validation efforts at both CSU and the University of Minnesota are complementing the code development. A screening of advanced superalloy, refractory metal alloy, and ceramic materials has been completed, and materials have been selected for creep and joining characterization as part of developing a high-temperature heater head. A breadboard characterization is underway for an advanced controller using power electronics for active power factor control with a goal of eliminating the heavy tuning capacitors that are typically needed to achieve near unity power factors. Key Stirling developments just initiated under recent NRA (NASA Research Announcement) awards will also be discussed. These include a lightweight convertor to be developed by Sunpower Inc. and an advanced microfabricated regenerator to be done by CSU.
\end{abstract}

\section{INTRODUCTION}

Under the auspices of NASA's Project Prometheus, the Nuclear Systems Program, the Department of Energy (DOE), Lockheed Martin (LM) of Valley Forge, PA, Stirling Technology Company (STC) of Kennewick, WA, and NASA Glenn Research Center (GRC) are developing a high-efficiency Stirling Radioisotope Generator (SRG) for possible use on future NASA Space Science missions. The SRG is being developed for multimission use (e.g., in environments with and without atmospheres), including providing electric power for unmanned Mars rovers and deep space missions. The SRG will provide a high-efficiency power source alternative to Radioisotope Thermoelectric Generators (RTG's). The SRG system efficiency of greater than $20 \%$ would reduce the required amount of radioisotope by a factor of four or more compared to RTG's. This significantly reduces radioisotope cost, radiological inventory, and system cost.

LM, under contract to DOE, is the System Integration Contractor for the SRG. LM is now developing the SRG engineering unit, with contract options to develop the qualification unit and the first flight units. The SRG concept is described by Cockfield and Chan (2002). The SRG is expected to produce about $114 \mathrm{Wdc}$ at beginning-of-mission (BOM) using two opposed Stirling convertors and two General Purpose Heat Source (GPHS) modules. The system efficiency is projected to be $23 \%$ and the $\mathrm{BOM}$ specific power about $4.2 \mathrm{~W}_{\mathrm{e}}$ (watts electric) $/ \mathrm{kg}$.

STC first developed the Stirling convertor under contract to DOE and is continuing development as a subcontractor to LM. This Technology Demonstration Convertor (TDC) is now being transitioned to a flight prototype convertor. A total of 16 TDC's have been built by STC, and these are now on test at STC, LM, and GRC. The latest four were built with additional quality assurance practices that STC has implemented to prepare for flight convertor fabrication. GRC provides technical consulting for the TDC development under a Space Act Agreement with DOE. 
GRC is also conducting an in-house technology project to assist in developing the convertor for space qualification and mission implementation. This includes independent verification testing of the TDC's, heater head life assessment, permanent magnet aging characterization, linear alternator evaluations, launch environment characterization testing, electromagnetic interference and electromagnetic compatibility characterization and reduction, organic materials evaluations, reliability studies, and fastener evaluation (Thieme and Schreiber, 2003; Schreiber and Thieme, 2003). GRC has recently begun extended operation of two of the most recent TDC's built by LM and STC, and about 2000 hours of testing have been accumulated to date. Preparations are also underway for a planned three-year test of two TDC's in a thermal vacuum environment. Primary creep testing on the Inconel 718 material that will be used to build the convertors for the SRG engineering unit and any first flight convertors has been completed. Heater head life estimates for a desired reliability have been made for various convertor hot-end temperatures, using the latest probabilistic analysis of the GRC IN718 creep data. Heater head structural benchmark tests have been started and will be used to calibrate and validate the heater head life assessment model. Long-term magnet aging tests of the neodymium-iron-boron $(\mathrm{NdFeB})$ permanent magnets used in the TDC linear alternators have reached 18,000 hours. Cure kinetics testing has been completed on the epoxy for the critical magnet/stator lamination bond. A plan has been developed for reliability analyses, and this effort is now getting underway.

GRC has also initiated efforts to develop advanced Stirling technologies. Performance and mass improvement goals have been established for second- and third-generation Stirling radioisotope power systems. Multiple efforts are underway to achieve these goals, both in-house at GRC and under various grants and contracts. These efforts include development of a multi-dimensional Stirling computational fluid dynamics code, high-temperature materials, advanced controllers, an end-to-end system dynamics model, low-vibration techniques, advanced regenerators, and a lightweight convertor. This paper will discuss the status and recent results for the Stirling advanced technology work.

\section{STIRLING ADVANCED TECHNOLOGY GOALS}

The overall objective of the advanced technology efforts is to develop a high efficiency, low mass Stirling convertor for use with a radioisotope, reactor, or solar concentrator heat source. The current work is focused on improvements for the SRG. Figure 1 shows performance and mass improvement goals for second- and third-generation Stirling radioisotope power systems. The first-generation system is the SRG currently being developed by LM. Reducing mass is the primary focus for the second-generation system, while the third-generation improvements primarily aim at improving efficiency. Mass improvements are based on using a lightweight Stirling convertor that significantly reduces the convertor mass and an advanced controller using power electronics to eliminate tuning capacitors. The goal of improving the high SRG efficiency to even greater values, 30 to $35 \%$, will be pursued by increasing both the Carnot efficiency and the percentage of Carnot efficiency that is achievable. Advanced superalloys, refractory metal alloys, and ceramics are being evaluated for a high-temperature heater head to increase the convertor temperature ratio and thus the Carnot efficiency. Achieving the higher percentage of Carnot efficiency is expected from convertor efficiency improvements based on multi-dimensional CFD analysis and improved regenerators. The goal is to improve the percentage of Carnot efficiency achieved from its present $45 \%$ to 55 to $60 \%$.

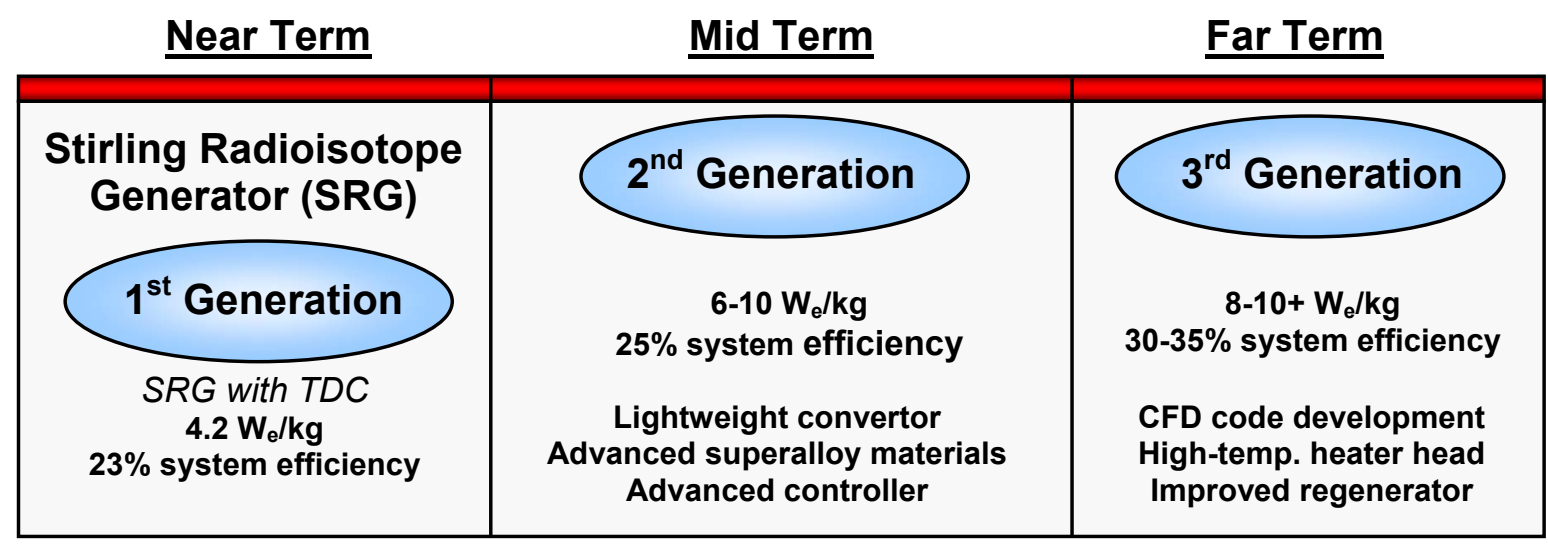

FIGURE 1. Stirling Advanced Technology Development Goals. 


\section{MULTI-DIMENSIONAL STIRLING CFD CODE}

Under grant from GRC, Cleveland State University (CSU) is developing a multi-dimensional Stirling computational fluid dynamics (CFD) code to significantly improve Stirling loss predictions and assist in identifying convertor areas for further improvements. The University of Minnesota (UMN) and Gedeon Associates, Athens, $\mathrm{OH}$ are teamed with CSU for this effort. The current status of this code development is given by Tew et al. (2004). Key existing one-dimensional Stirling performance and design codes agree reasonably well with each other in terms of overall performance but can differ significantly in the magnitude of specific internal losses. Also, one-dimensional codes do not rigorously model manifolds and area changes between heat exchangers and expansion/compression spaces in the convertor. It is expected that this CFD code should give a significant improvement in the understanding of these losses and convertor design areas and, thus, help lead to further performance improvements. It is also expected that the development of the code and the supporting validation effort will lead to improvements in the 1-D codes as well.

The commercial code, CFD-ACETM, developed by CFD Research Corporation, Huntsville, AL has been chosen for the CFD code development. A 2-D model of a Stirling convertor is now operational and is being further upgraded to include models of the appendix gap and seal regions. Some approximations to actual 3-D geometries, including those for the heater and cooler heat exchangers, were necessary for the 2-D axisymmetric model. This initial model uses a porous media module, included with the CFD-ACETM code, for simulating the regenerator matrix. Initial runs with the 2-D model have raised questions relative to the use of the porous media module for this application, and these issues are currently being investigated. This 2-D model is now being modified at GRC to model the TDC. Work on 3-D models has also been started. One key issue is the amount of processing time needed to run a complete 3-D model of a convertor. GRC has purchased an initial set of eight computers to begin building a parallel cluster to significantly increase processing speed.
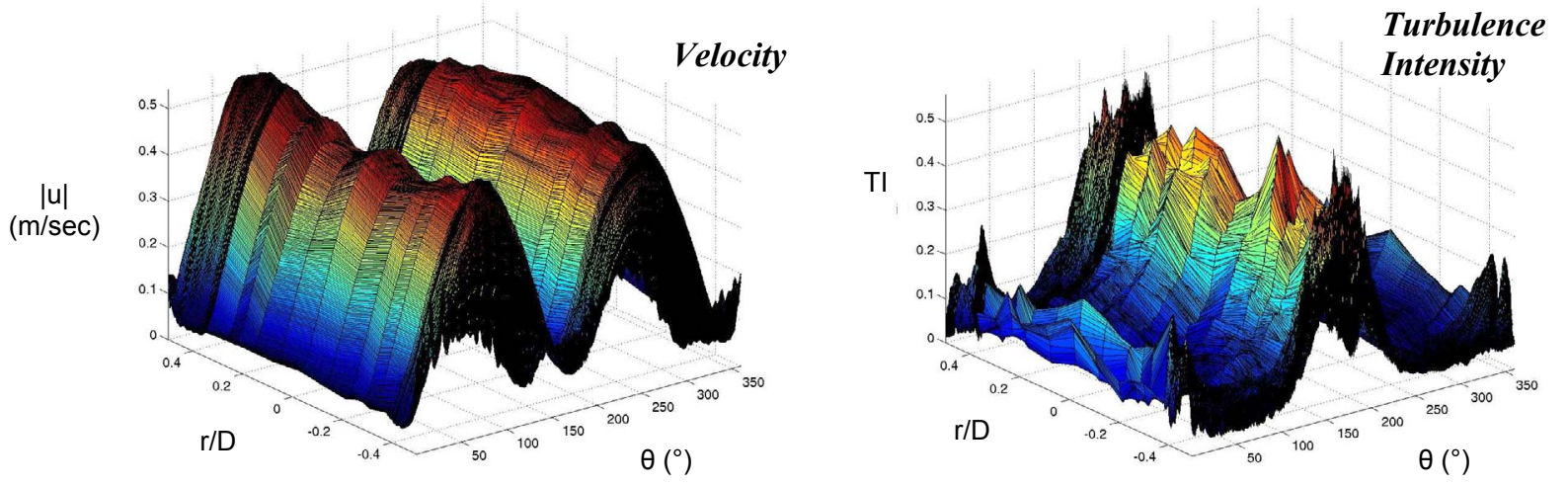

FIGURE 2. Sample Velocity and Turbulence Intensity Profiles.

A significant amount of the effort underway is aimed at validating the Stirling CFD code. Testing has been completed with a "90-degree turn" test section at the UMN. A hot-wire anemometer was recently used to measure velocity and turbulence intensity profiles to add to earlier flow visualization test results. Both oscillating flow and unidirectional flow tests were completed. These tests are described by Adolfson et al. (2003). Sample velocity (u) and turbulence intensity (TI) $\left(\mathrm{TI}=\mathrm{u}_{\mathrm{rms}} /|\mathrm{u}|\right)$ data for oscillating flow are shown in Figure 2. The hot-wire anemometer is unable to resolve flow direction so absolute velocity values are plotted. Adolfson states that periods of strong acceleration (e.g. $0^{\circ}<\theta<45^{\circ}$ ) show dissipation of turbulence, whereas periods of deceleration (e.g. $90^{\circ}<\theta$ $<135^{\circ}$ ) show large production of turbulence. This is in agreement with the flow visualization results. CSU modeled the UMN test rig for comparing test data to the CFD code; code and test results are compared by Ibrahim et al. (2003a). The UMN rig was modeled using 1) laminar flow, 2) a K- $\omega$ turbulence model, and 3) a K- $\varepsilon$ turbulence model. Laminar flow predictions gave good agreement in the stagnation regions while turbulent flow predictions with the $\mathrm{K}-\omega$ model compared well at radial distances further from the stagnation regions. A sample comparison with the UMN flow visualization results is shown in Figure 3. Note that the flow features including the large-scale vortex generated between the two discs of the "90-degree turn" test section are predicted very well by the code with the K- $\omega$ turbulent model. A "180-degree turn" test section that better simulates the flow situation in a Stirling convertor is now under design; heat transfer will also be measured with this test section. CSU has also recently started operation of a test rig to provide further code validation data. 

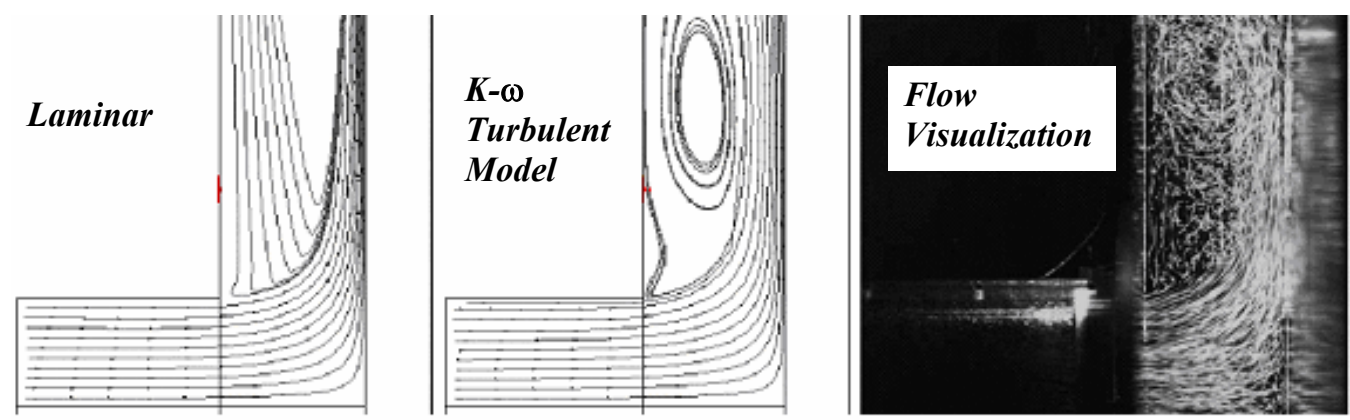

FIGURE 3. Sample Comparison Between CFD Predictions and UMN Flow Visualization Experiments.

A second CSU grant effort is studying the effects of oscillating flow and oscillating pressure on heat transfer in the Stirling convertor working spaces. The 1-D code SAGE and CFD-ACETM are being used to analyze test rig data taken previously at the Massachusetts Institute of Technology. The goal is to improve heat transfer and loss calculations in the 1-D codes and eventually lead to a second law analysis post processor for the multi-dimensional CFD code. A second law post processor is included in the 1-D SAGE code. It has proven to be a useful tool for segregating and understanding thermodynamic losses in Stirling convertors and thus assisting in the development of improved designs that minimize these losses.

\section{HIGH-TEMPERATURE MATERIALS}

The TDC maximum hot-end temperature is $650{ }^{\circ} \mathrm{C}$, with a design lifetime of about 120,000 hours. The heater head is fabricated from the nickel-base superalloy Inconel 718 (IN718). Higher-temperature materials, including advanced superalloys, refractory metal alloys, and ceramics are being evaluated to increase the convertor hot-end temperature (Bowman, Ritzert, and Freedman, 2004). This would achieve a higher Carnot efficiency based on the increased operating temperature ratio, allow an increased cold-end temperature to reduce radiator mass if system mass optimizations indicated this was preferable, or some combination of the two. Advanced superalloys could allow operation at 750 to $850^{\circ} \mathrm{C}$, while refractory metal alloys and ceramics could achieve up to about $1200{ }^{\circ} \mathrm{C}$ for these required lifetimes. The maximum hot-end temperature may need to be restricted to about $1050{ }^{\circ} \mathrm{C}$ for a radioisotope power system to maintain the radioisotope heat source within its temperature limits while operating in a vacuum. This maximum hot-end temperature with a refractory metal alloy or ceramic heater head may possibly be increased to 1125 to $1200{ }^{\circ} \mathrm{C}$ by using a cover gas on the radioisotope heat source to decrease internal temperature drops; a combined Stirling convertor/cooler with this heater head and radioisotope heat source could then potentially enable an extended-duration surface mission on Venus.

The Stirling convertor will be operating continuously once the radioisotope fuel is loaded. Under this scenario, creep becomes the dominant failure mechanism that needs to be considered for the heater head lifetime. The following criteria were used to screen the various candidate materials: 1) creep properties, 2) fabricability, 3) helium gas containment, 4) long-term stability/compatibility, 5) ability to form a hermetic close-out seal, and 6) ductility/toughness (to assist in fabrication, handling, and resistance to foreign object damage).

\section{Advanced Superalloys}

Based on general superalloy properties, the 120,000-hour life requirement roughly gives a maximum use temperature of about $850^{\circ} \mathrm{C}$. The key factors for the superalloy evaluation were creep properties, hermetic sealing, and stability. Very little creep data exist for long lifetimes, and the vast majority are for tests with a rupture life of less than 10,000 hours. Also, creep properties are sensitive to the sample thickness-to-grain size ratio, and thin-wall test data will be needed to properly characterize any material for the thin-walled Stirling heater head. For this study, Larson-Miller plots were used to compare creep data. Creep testing will be conducted on any candidate materials to supplement the creep database in the literature. Special consideration was given to materials with a high degree of stability due to the long-life requirement and also recognizing that long-term data on these materials generally does not exist. Joining is a critical material property since superalloys are typically difficult to weld with fusion-welding techniques that melt the base metal, due to cracking in post-weld thermal treatments. The empirical parameter of 
2Al+Ti was used evaluate weldability; higher-strength alloys with higher amounts of aluminum ( $\mathrm{Al})$ and titanium (Ti) are typically the most difficult to weld. Solid-state welding techniques that don't melt the base alloy such as friction, projection, and magnetic pulse welding and other techniques such as brazing, transient liquid phase bonding, and diffusion bonding are also being pursued.

Five candidate nickel-based superalloys were selected for further study. Each has superior creep properties compared to IN718, but there are also issues with each that could prevent successful use. The materials selected are Udimet 720, IN738LC, IN939, MarM 247, and MA754. These include wrought, cast, and mechanically-alloyed superalloys. They also cover a range of potential temperature improvement versus risk tradeoffs. See Bowman, Ritzert, and Freedman (2004) for a discussion of the strengths and weaknesses of each of these material candidates.

\section{Refractory Metal Alloys}

Refractory metal alloys that were given primary consideration included alloys based on molybdenum, niobium, tantalum, tungsten, and rhenium. Other candidates were not considered due to limited availability and high cost. One issue with the refractory metal alloys is that they typically have a much smaller database than the superalloys, thus making long-term life predictions more uncertain. Also, they must be tested in an inert environment due to oxidation effects at the hot operating temperature. A significant amount of work was done on refractory metal alloys as part of the SP-100 program to develop a 100-kW nuclear space power system that ended in the early 1990's.

The most promising refractory metal alloys are those based on tantalum and tungsten. Tantalum alloys are highly developed, and ASTAR-811C was chosen as the primary refractory metal alloy for further study. ASTAR-811C is promising due to its high melting temperature, high strength, good weldability and fabricability, and ductility at low temperatures. One issue is that it is highly affected by processing. At the highest temperatures, tungsten alloys may be possible successors to the ASTAR family but now have very limited creep data and issues with respect to welding and maintaining non-brittle characteristics. Molybdenum alloys were considered high risk due to concern over the alloys maintaining strength and non-brittle characteristics after welding. Niobium alloys were thought to have only marginal advantages compared to the high-strength superalloys.

In addition to ASTAR-811C, rhenium was also chosen for further investigations due to its excellent hightemperature strength and low-temperature ductility. It also has good weldability and fabricability. However, the rhenium database is very limited, so rhenium is considered to be a high-risk candidate but with very high potential benefits.

\section{Ceramics}

Ceramic materials offer a number of significant advantages over superalloys for the Stirling heater head application including higher-temperature capability, more creep resistance, and a wider range of thermal conductivities. Ceramics may allow tailoring for high radial thermal conductivity and low axial thermal conductivity to control heat conduction losses between the hot end and cold end of the Stirling convertor. This loss is especially significant for these lower-power level systems. Also, ceramics do not require testing in an inert environment as do the refractory metal alloys. Disadvantages of ceramics include a lower coefficient of thermal expansion compared to the metals to which they will be attached, higher helium permeability, and higher manufacturing costs.

A basic ceramic heater head design was generated. This could consist of up to four elements: damage shield, ceramic structural component, helium diffusion/permeation barrier, and heat sink. The damage shield is the outer structure and protects the heater head during handling and use. A ceramic matrix composite is proposed for the damage shield with the fiber reinforcements designed to provide high radial thermal conductivity in the heater and cooler heat exchanger regions and low axial thermal conductivity between them (in the regenerator region). The ceramic structural component is the main load-bearing component of the heater head. The initial choice is a fully dense monolithic silicon carbide, either continuous with or bonded to the damage shield. Monolithic silicon nitride is a second choice and may allow easier control of the microstructure to obtain high radial and low axial thermal conductivities. A helium diffusion/permeation barrier can be included if test data confirms the need for this. A silica coating on the inside of the ceramic structural component will first be investigated; it could also be a metal or metal coating. Finally, a heat sink with high thermal conductivity could be attached to interface to the radiator. This could 
be a fully-dense CVI (chemical vapor infiltration) silicon carbide, either continuous with or bonded to the ceramic structural component, or a carbon-carbon composite.

The primary issues for developing a ceramic heater head are: 1) helium permeability through the ceramic structure, 2) the ceramic-metal joint, and 3) assembly and testing of the complete heater head structure. Damage tolerance must also be addressed. Helium permeability tests are now being run on selected candidate materials.

\section{ADVANCED CONTROLLER}

Although the controller design can often be application specific, there are many features that are common to most controllers for Stirling convertors. Among these are power quality (low ripple), low mass, high efficiency, low parts count, high reliability, low volume, and adaptability. Furthermore, as some applications may require very low levels of vibratory emissions, the controller could be used to influence the operating dynamics to achieve a finely balanced system. GRC has a controller technology effort intended to develop key technologies necessary for these advanced controllers. The development will initially address mass and volume reduction and then low-vibration operation.

The first effort was the development of a controller that is an outgrowth of an SP-100 era controller and is known as the digital controller. This controller used digital logic to apply an analog load to maintain control of the convertor. The original digital controller had an undesirable characteristic that allowed the alternator output voltage to vary slightly as the power output changed. A newer version, the second-generation digital controller, is able to maintain constant output voltage. This controller is used in the GRC Stirling Research Laboratory, along with the original digital controller and the STC-developed zener diode controller, for general performance testing.

The first area being investigated for advanced controllers is the elimination of the tuning capacitors found in most controllers. These capacitors contribute significantly to the mass and volume of the controller. The linear alternator tends to be an inductive device and tuning capacitors are commonly used to correct the power factor back to unity. In electrical terms, this results in the current and voltage being in phase with one another; in the context of the mechanical spring-mass-damping dynamics of the free-piston Stirling, this results in the damping provided by the

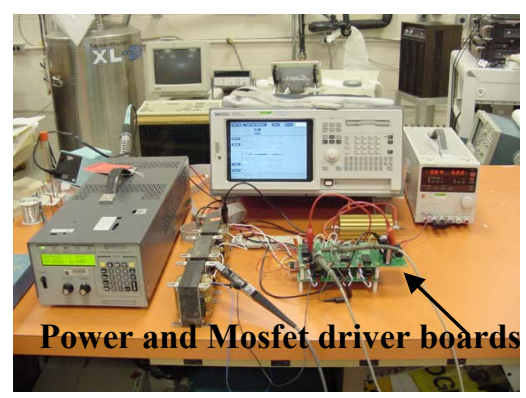

FIGURE 4. Power and Mosfet driver boards for advanced controller on test at GRC. load being in phase with the velocity of the piston. Techniques are available through the use of power electronics to, in essence, force the current that flows through the alternator to be in phase with the voltage through high speed switching controlled by a microprocessor. This technique has more often been applied to control the power supplied to a motor; however, there are a few examples of this being used to control or process power being generated. This technique is known as Active Power Factor Correction (PFC). Two such controllers with Active PFC have been developed at GRC. These circuits are referred to as first- and second-generation Active PFC controllers. Both circuits have been tested on the bench with Stirling convertor simulators. Functional testing of the second-generation Active PFC controller with a signal generator is shown in Figure 4. Tests with the controllers operating on a Stirling convertor are being planned.

Following development and characterization of the Active PFC technology on a single Stirling convertor, the technology will then be applied to a pair of convertors operating in the dual-opposed configuration. This configuration provides inherent dynamic balancing of the moving components. While this inherently achieves low vibration, it can only do so within the limitations of the manufacturing tolerances. To achieve lower levels of vibratory emissions, a technique will be investigated that calls upon the controller to alter the dynamics of one convertor relative to the other, to reach a superior level of balance. Some of the options to be explored include varying the tuning capacitance applied to one of the alternators or injecting a precise signal into one of the alternators to influence the piston motion to improve balance. Similar techniques have been demonstrated in cryocoolers at GRC; however, they have not been applied to power convertors. One key difference between power convertors and cryocoolers is that the operating frequency is not constant in power convertors. A literature review of past work in this area is now being completed. Some previous work completed by STC in low-vibration techniques for power convertors is discussed in Thieme, Qiu, and White (2000). 


\section{LIGHTWEIGHT STIRLING CONVERTOR}

Sunpower, Inc., Athens, OH has recently won a NASA Research Announcement (NRA) award for Radioisotope Power Conversion Technology to develop a lightweight Stirling convertor for radioisotope space power systems (Wood and Lane, 2004). This convertor is expected to be significantly lighter than the TDC currently used in the SRG. Based on its projected mass and performance, it would approximately double the specific power of a second-

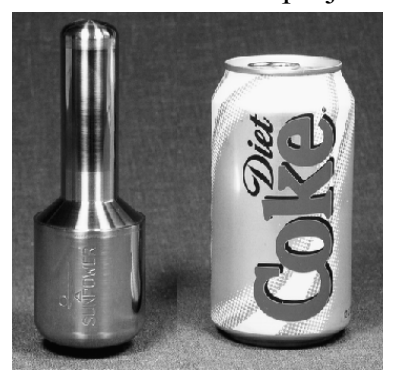

FIGURE 5. Mockup of Lightweight Convertor (courtesy of Sunpower, Inc.). generation Stirling radioisotope power system (producing a nominal DC power output of $120 \mathrm{~W}$ ) to about $8 \mathrm{~W}_{\mathrm{e}} / \mathrm{kg}$. It will be sized for two convertors operating in an opposed, balanced configuration and using the heat from two GPHS modules. The convertor is projected to have a specific power of nearly $100 \mathrm{~W}_{\mathrm{e}} / \mathrm{kg}$ and an efficiency of $30 \%$ or greater. Sunpower has teamed with Boeing-Rocketdyne, Canoga Park, CA for this development. Two generations of convertors will be built. The first will be a research convertor designed to allow for tear-down and change out of components. The second-generation convertor will demonstrate the final lightweight hermetically sealed design. A test bed convertor will also be used to verify efficiency predictions, study frequency effects on efficiency, and assist in testing advanced components. BoeingRocketdyne will provide the controller and evaluate high-temperature materials. CSU and UMN will provide CFD modeling and heat transfer testing/analysis to assist in studying specific convertor losses.

Sunpower is also developing a lower-power convertor, shown in Figure 5, under a NASA Phase II SBIR. This is sized for two convertors operating in an opposed, balanced configuration and using the heat from one GPHS module (Wood and Lane, 2004). The first convertor of this effort is now under test and has achieved over $40 \mathrm{~W}$ AC output with no restriction on heat input. GRC is planning to do a launch environment test of this convertor in 2004.

\section{REGENERATORS}

Over the last several years, CSU has been conducting a research effort for DOE-Golden to improve the performance of solar terrestrial Stirling convertors. CSU has teamed with UMN, Gedeon Associates, and GRC on this effort, which has focused on better understanding and improving the Stirling regenerator. The team has studied, both experimentally and with CFD analysis, such items as plenum size effects on jetting into the regenerator, flow recirculation near the regenerator wall, and measurement of heat transfer rates between the regenerator wires and fluid. Recent results are described by Niu et al. (2003a and 2003b) and Ibrahim et al. (2003b). This effort is also aiding the development of the regenerator model for the multi-dimensional CFD code. This work is now expected to be continued under NASA grant funding. The NASA grant will focus on improving currently-used random fiber regenerators and possibly foil regenerators, obtaining a better understanding of detailed regenerator flow fields and heat transfer in oscillating flow, and determining heat transfer characteristics of high-porosity Stirling regenerators.

CSU recently won a NRA award for Radioisotope Power Conversion Technology to conduct a research effort for a microfabricated regenerator. CSU is teamed with UMN, Gedeon Associates, STC, and Sunpower. Several regenerator designs are under consideration, and several possible manufacturing processes and manufacturers have been identified. A large-scale mockup of the selected design will be tested at UMN and modeled by CSU and Gedeon Associates. A prototype, proof-of-concept regenerator matrix with actual size features will then be built and tested in an oscillating flow rig at Sunpower. As a final demonstration, a microfabricated regenerator matrix will be tested, as possible, in STC and/or Sunpower convertors. Microfabricated regenerators could potentially improve Stirling convertor performance, increase regenerator durability, and improve fabrication consistency.

\section{SYSTEM DYNAMICS MODEL}

The development of an end-to-end system dynamics model is continuing (Regan, Gerber, and Roth, 2003). This model includes the Stirling engine thermodynamics, linear alternator, controller, and load. Simulations of systems with multiple Stirling convertors have been performed successfully. A library of various controller models has been completed. TDC data has been taken for comparisons with the model predictions, and this comparison has now been started. 


\section{CONCLUDING REMARKS}

Stirling advanced technology development efforts are in their early stages, but good progress was made in 2003 toward achieving the performance and mass improvement goals for second- and third-generation Stirling radioisotope power systems. These advanced systems could provide significant performance and mass benefits for Mars rovers and deeps space missions and could also allow the use of Stirling radioisotope power systems for radioisotope electric propulsion and Venus surface missions. Key work, under a NASA NRA, has begun on the development of a lightweight Stirling convertor that is expected to double the system specific power to about 8 $\mathrm{W}_{\mathrm{e}} / \mathrm{kg}$. Efforts on the multi-dimensional Stirling CFD performance code, high-temperature materials, and advanced controllers are progressing well. GRC's close integration with the team developing the first-generation Stirling Radioisotope Generator should provide a good path to eventual use of advanced technology developments.

\section{REFERENCES}

Adolfson, D.A., Simon, T.W., Ibrahim, M.B., and Gedeon, D., "Unsteady Fluid Dynamics Simulation of a Stirling Engine Heater Head," Proceedings of the 1st International Energy Conversion Engineering Conference, Portsmouth, VA, Paper No. AIAA-2003-5934, 2003.

Bowman, R., Ritzert, F., and Freedman, M., "Evaluation of Candidate Materials for a High-Temperature Stirling Convertor Heater Head," in these proceedings of Space Technology and Applications International Forum, edited by M.S. El-Genk, American Institute of Physics, Melville, NY, 2004.

Cockfield, R.D. and Chan, T.S., "Stirling Radioisotope Generator for Mars Surface and Deep Space Missions," Proceedings of the 37th Intersociety Energy Conversion Engineering Conference, Washington, DC, IECEC 2002 Paper No. $20188,2002$.

Ibrahim, M.B., Zhang, Z., Kembhavi, S., Simon, T.W., Tew, R., and Gedeon, D., "A Model of 90 Degree Turn Oscillatory Flow," Proceedings of the 1st International Energy Conversion Engineering Conference, Portsmouth, VA, Paper No. AIAA-2003-5935, 2003a.

Ibrahim, M.B., Rong, W., Simon, T.W., Tew, R., and Gedeon, D., "Microscopic Modeling of Unsteady Convective Heat Transfer in a Stirling Regenerator Matrix," Proceedings of the 1st International Energy Conversion Engineering Conference, Portsmouth, VA, Paper No. AIAA-2003-6016, 2003b.

Niu, Y., Simon, T.W., Ibrahim, M.B., Tew, R., and Gedeon, D., "Measurements of Unsteady Convective Heat Transfer Rates within a Stirling Regenerator Matrix Subjected to Oscillatory Flow," Proceedings of the 1st International Energy Conversion Engineering Conference, Portsmouth, VA, Paper No. AIAA-2003-6013, 2003a.

Niu, Y., Simon, T.W., Ibrahim, M.B., Tew, R., and Gedeon, D., "Jet Penetration into a Stirling Engine Regenerator Matrix with Various Regenerator-to-Cooler Spacings," Proceedings of the 1st International Energy Conversion Engineering Conference, Portsmouth, VA, Paper No. AIAA-2003-6014, 2003b.

Regan, T.F., Gerber, S.S., and Roth, M.E., "Development of a Dynamic, End-to-End Free Piston Stirling Convertor Model," in proceedings of Space Technology and Applications International Forum (STAIF 2003), edited by M. El-Genk, AIP Conference Proceedings 654, Melville, New York, 2003, pp. 635-640.

Schreiber, J.G. and Thieme, L.G., "Overview of NASA GRC Stirling Technology Development," presented at the 1st International Energy Conversion Engineering Conference, Portsmouth, VA, Paper No. AIAA-2003-6093, 2003.

Tew, R., et al., "Overview 2003 of NASA Multi-D Stirling Convertor Code Development and DOE \& NASA Stirling Regenerator R\&D Efforts," in these proceedings of Space Technology and Applications International Forum, edited by M.S. El-Genk, American Institute of Physics, Melville, NY, 2004.

Thieme, L.G., Qiu, S., and White, M.A., "Technology Development for a Stirling Radioisotope Power System," in proceedings of Space Technology and Applications International Forum (STAIF 2000), edited by M. El-Genk, AIP Conference Proceedings 504, Melville, New York, pp. 1260-1265, NASA/TM-2000-209791, 2000.

Thieme, L.G. and Schreiber, J.G., "NASA GRC Stirling Technology Overview," in proceedings of Space Technology and Applications International Forum (STAIF 2003), edited by M. El-Genk, AIP Conference Proceedings 654, Melville, New York, pp. 613-620, NASA/TM-2003-212454, 2003.

Wood, J.G. and Lane, N., “Advanced Small Free-Piston Stirling Convertors for Space Power Applications," in these proceedings of Space Technology and Applications International Forum, edited by M.S. El-Genk, American Institute of Physics, Melville, NY, 2004. 

Public reporting burden for this collection of information is estimated to average 1 hour per response, including the time for reviewing instructions, searching existing data sources, gathering and maintaining the data needed, and completing and reviewing the collection of information. Send comments regarding this burden estimate or any other aspect of this collection of information, including suggestions for reducing this burden, to Washington Headquarters Services, Directorate for Information Operations and Reports, 1215 Jefferson Davis Highway, Suite 1204, Arlington, VA 22202-4302, and to the Office of Management and Budget, Paperwork Reduction Project (0704-0188), Washington, DC 20503.

\begin{tabular}{|l|l|l|}
\hline 1. AGENCY USE ONLY (Leave blank) & $\begin{array}{c}\text { 2. REPORT DATE } \\
\text { September } 2004\end{array}$ & $\begin{array}{r}\text { 3. REPORT TYPE AND DATES COVERED } \\
\text { Technical Memorandum }\end{array}$ \\
\hline
\end{tabular}

\section{TITLE AND SUBTITLE} 5. FUNDING NUMBERS

Advanced Technology Development for Stirling Convertors

\section{AUTHOR(S)}

Lanny G. Thieme and Jeffrey G. Schreiber

WBS-22-972-30-01 and WBS-22-319-20-R1

\section{PERFORMING ORGANIZATION NAME(S) AND ADDRESS(ES)}

National Aeronautics and Space Administration

John H. Glenn Research Center at Lewis Field

Cleveland, Ohio 44135-3191

8. PERFORMING ORGANIZATION REPORT NUMBER

\section{E-14685}

\section{SPONSORING/MONITORING AGENCY NAME(S) AND ADDRESS(ES)}

10. SPONSORING/MONITORING AGENCY REPORT NUMBER

National Aeronautics and Space Administration

Washington, DC 20546-0001

NASA TM-2004-213186

\section{SUPPLEMENTARY NOTES}

Prepared for the Space Technology and Applications International Forum (STAIF-2004) sponsored by the American Institute of Physics, Albuquerque, New Mexico, February 8-12, 2004. Responsible person, Lanny G. Thieme, organization code 5490, 216-433-6119.

\section{2a. DISTRIBUTION/AVAILABILITY STATEMENT}

12b. DISTRIBUTION CODE

Unclassified - Unlimited

Subject Categories: 20 and 44

Distribution: Nonstandard

Available electronically at http://gltrs.grc.nasa.gov

This publication is available from the NASA Center for AeroSpace Information, 301-621-0390.

\section{ABSTRACT (Maximum 200 words)}

A high-efficiency Stirling Radioisotope Generator (SRG) for use on potential NASA Space Science missions is being developed by the Department of Energy, Lockheed Martin, Stirling Technology Company, and NASA Glenn Research Center (GRC). These missions may include providing spacecraft onboard electric power for deep space missions or power for unmanned Mars rovers. GRC is also developing advanced technology for Stirling convertors, aimed at substantially improving the specific power and efficiency of the convertor and the overall power system. Performance and mass improvement goals have been established for second- and thirdgeneration Stirling radioisotope power systems. Multiple efforts are underway to achieve these goals, both in-house at GRC and under various grants and contracts. The status and results to date for these efforts will be discussed in this paper. Cleveland State University (CSU) is developing a multi-dimensional Stirling computational fluid dynamics code, capable of modeling complete convertors. A 2-D version of the code is now operational, and validation efforts at both CSU and the University of Minnesota are complementing the code development. A screening of advanced superalloy, refractory metal alloy, and ceramic materials has been completed, and materials have been selected for creep and joining characterization as part of developing a high-temperature heater head. A breadboard characterization is underway for an advanced controller using power electronics for active power factor control with a goal of eliminating the heavy tuning capacitors that are typically needed to achieve near unity power factors. Key Stirling developments just initiated under recent NRA (NASA Research Announcement) awards will also be discussed. These include a lightweight convertor to be developed by Sunpower Inc. and an advanced microfabricated regenerator to be done by CSU.
14. SUBJECT TERMS
Stirling engines; Nuclear electric power generation; Deep space; Mars; Roving vehicles; Controllers;
Computational fluid dynamics; Heat resistant alloys; Refractory metals; Ceramics; Regenerators; Dynamics

\begin{tabular}{|c|c|c|}
\hline $\begin{array}{c}\text { 17. SECURITY CLASSIFICATION } \\
\text { OF REPORT } \\
\text { Unclassified }\end{array}$ & $\begin{array}{c}\text { 18. SECURITY CLASSIFICATION } \\
\text { OF THIS PAGE } \\
\text { Unclassified }\end{array}$ & $\begin{array}{c}\text { 19. SECURITY CLASSIFICATION } \\
\text { OF ABSTRACT } \\
\text { Unclassified }\end{array}$
\end{tabular}

\section{NUMBER OF PAGES}

16. PRICE CODE 20. LIMITATION OF ABSTRACT

Standard Form 298 (Rev. 2-89)

Prescribed by ANSI Std. Z39-18 298-102 

